\title{
EFFICACY OF GARLIC (ALLIUM SATIVUM) ON STAPHYLOCOCCUS AUREUS CONJUNCTIVITES
}

\author{
BY
}

*UZODIKE, E. B. AND IGWE, I. C.

DEPARTMENT OF OPTOMETRY, ABIA STATE UNIVERSITY,

UTURU, ABIA STATE, NIGERIA

Email: ebeluzo@yahoo.com

*corresponding author

\section{ABSTRACT}

This research work was aimed at determining the efficacy of garlic extract (GE) on staphylococcus aureus (S. aureus) conjunctivitis. The experiment was carried out in vitro and in vivo. Double dilution method, minimum inhibitory concentration (MIC) and zone of inhibition were used in the two investigations to determine this efficacy. GE efficacy was also compared to that of a know antibioticgentamycin. The data obtained were analyzed using tables, t-test and Chi square Yate's correction for continuity. Results showed MIC to be $31.25 \mathrm{mg} / \mathrm{ml}$. GE (stock) efficacy was comparable to gentamycin drug as both resolved $S$. aureus infection within 8 and 6 days (respectively) of treatment while appreciable growth was recorded in the control group 15 days post infection. Statistical result using Chi-square showed that sensitivity of $\mathrm{S}$. auerus and type of treatment were independent. T-test showed that sensitivity of S. aureus to GE was statistically significant $(\mathrm{p}>0.0 .5)$.

KEYWORDS: Staphylococcus aureus, Garlic extract, Conjunctivitis, Gentamycin, Bioload, Double dilution.

\section{INTRODUCTION}

Bacterial conjunctivitis is common usually self-limiting. The most common causative organisms are staphylococcus epidermis and staphylococcus aureus (S. aureus). Bacterial conjunctivitis is rarely sight threatening. However, accurate diagnosis and prompt treatment at the primary level is important as it instills confidence in the community and reduces the risk that people may first try traditional remedies which can, and do lead to blindness ${ }^{1}$. The preparations put into the eye can cause corneal ulcers or worsen existing ones and may end up as scars or eye perforations leading to blindness ${ }^{2}$.

A wide range of microorganisms including bacteria, fungi, protozoa and viruses has been shown to have some degree of sensitivity to crushed garlic preparation ${ }^{3}$. Garlic has also been found to produce inhibitory effects on gramnegative germs of the typhoid, paratyphoid enteritis groups. It indeed possesses outstanding germicidal properties and can keep amoebic dysentery at bay ${ }^{4}$. There is no doubt that garlic preparations could still be in use in various communities to treat bacterial conjunctivitis. Hence, this study aimed at examining the efficacy of garlic preparation on S. aureus conjunctivitis.

\section{MATERIALS AND METHODS}

This research work was conducted at the Microbiology laboratory of Abia State University, Uturu. Twenty fours rabbits with age ranging from five to six months were used as experimental animals. The animals were certified fit for the experiment by a renowned veterinary doctor. The animals were divided into three groups. Group A (GPA) was treated with garlic extract (GE), Group B (GPB) was treated with Gentamycin eye drop $\left(0.3 \%\right.$ Evril $\left.^{\circledR}\right)$ and Group C (GPC) was the control and received no treatment.

Evril $^{\circledast}$ eye drop used was manufactured by Medreich Sterilab Ltd, India, and batch no. 5034002 with expiring date December 2006. A botanist authenticated fresh Garlic used. GE used was obtained under standard hygienic condition and different concentrations were obtained using double dilution method from the stock (undiluted garlic extract). Fresh extract was obtained on daily basis to prevent degradation and contamination.

The experiment was carried out both in vitro and in Vivo. In Vitro, the sensitivity test was carried out on isolated $\mathrm{S}$. aureus. The minimum inhibitory concentration (MIC) of GE on S. aureus was determined according to Baron et $\mathrm{al}^{5}$. The double dilution was done to the third dilution. Sentient agar plates were seeded with S. aureus by spread plate method. ñWellsòwere made in the agar using $6 \mathrm{~mm}$ cork-borer and labeled according to different 
dilutions. Sterilized Pasteur pipettes were used to introduce 3 drops of different garlic dilutions and the stock into the ñWellò. The Plates were incubated at $37^{\circ} \mathrm{C}$ for 24hours. The zones of inhibition (ZOI) were then measured.

In vivo, the experimental animals were certified to be free of eye infections. They were denied food and water for 36 hours to weaken them so as to enhance induced infection. Using sterile swab stick isolated S. aureus was inoculated topically into the animals right eye and allowed to incubate for 48 hours. Treatment commenced when infection was confirmed. GPA was treated with fresh GE (stock concentration); GPB was treated with Evirl ${ }^{\circledR}$ while GPC received no treatment. The regimen was twice daily. Swabs were taken from the infected eye, every two days and cultured using spread plate method. The bacterial colonies were counted and recorded. The treatment and swabs taking (at the stated intervals) continued till the infection resolved. The data obtained were analyzed using tables, students' t-test (one tail) and Chi-square Yates correction for continuity.

\section{RESULTS}

Table 1 shows that zones of inhibition of GE and gentamycin eye drop on $S$. aureus were comparable. The average ZOI of GE was found to be $25 \mathrm{~mm}$ while that of gentamycin was $32.5 \mathrm{~mm}$. Table 2 shows that the sensitivity of $\mathrm{S}$. aureus to GE was concentration dependent; their relationship is directly proportional. MIC was found to be $31.25 \mathrm{mg} / \mathrm{ml}$. The highest mean bioload of $1.6 \times 10^{5}$ colony forming units (CFU) was recorded for GP $\mathrm{A}, 1.55 \times 10^{5} \mathrm{CFU}$ for GPB and $1.54 \times 10^{5} \mathrm{CFU}$ for GPC 48 hour post infection before commencement of treatment. Ninety-six (96) hours after infection, GPB showed the least corresponding mean bioload while GPC showed the highest mean bioload. The mean bioload in GPs A and B reduced drastically with treatment unlike in GPC. One hundred and ninety-two (192) hours post infection, GPA infection resolved completely. GPB had no significant mean bioload while GPC still had growth even at 336 hours after infection when the research was concluded (see table 3 ).

\section{DISCUSSION}

Antibacterial efficacy of GE on S. aureus was evident from the sensitivity test carried out in vitro and the treatment, which proved successful in vivo. These results were in comparison with gentamycin eye drop efficacy. Gentamycin is a drug of choice for the treatment of conjunctivitis especially $\mathrm{S}$. auerus conjunctivitis ${ }^{6}$.
ZOI of $32.5 \mathrm{~mm}$ diameter and $25 \mathrm{~mm}$ diameter was obtained for Evirl ${ }^{\circledR}$ and stock GE respectively. This showed a relatively high antibacterial effect. Chi-square Yates' correction for continuity showed that sensitively with $S$. aureus and type of treatment were independent. Therefore, GE could be used for the treatment of S. auerus conjunctiva. The MIC of the GE was gotten using the double dilution method of Baron et $\mathrm{al}^{5}$ in order to investigate the effect of different concentration on $\mathrm{S}$. aureus. The ZOI of GE with S. aureus was found to be concentration dependent. The concentration of $125 \mathrm{mg} / \mathrm{ml}$ had the highest effect with ZOI of $18.5 \mathrm{~mm}$ diameter while concentration of $31.25 \mathrm{mg} / \mathrm{m}$ had the least effect with ZOI $9.00 \mathrm{~mm}$ (Table 2). When the data was analyzed using t-test at 0.05 level of significance, the efficacy of garlic on S. aureus was found to be statistically significant $\left(\mathrm{t}_{\mathrm{ab}} 2.353<\mathrm{t}_{\mathrm{cal}} 4.51\right)$. This result is in line with Berwal $^{7}$ findings that all bacterial pathogens (S. aureus inclusive) tested were inhibited by garlic.

GE compared favourably with gentamycin in the treatment of S. aureus conjunctivitis. Fortyeight (48) hours post infection the three groups of animal had approximately the some bioload of $1.6 \times 10^{5} \mathrm{CFU}$; with various treatments, GPB's infection resolved on the $6^{\text {th }}$ day, GPA's infection resolved on the $8^{\text {th }}$ day while GPC's infection (control) that received no treatment did no resolved completely even at the 15 th day when monitoring was stopped. These findings support similar clinical trials and laboratory studies which showed that GE has antibacterial activity against $\mathrm{S}$. auerus including the resistant strains ${ }^{8,9}$.

Major component of garlic found to be responsible for much of the therapeutic and antimicrobial properties of garlic is Allicin. Allicin found in crushed garlic has a bacteriostatic effect against wide spectrum of microorganisms both gram-positive and gram-nagative $\mathrm{e}^{10}$ Allicin and Ajoene (an enzymatic product of allicin) block the enzymes that are necessary for these microorganisms' metabolism. They inhibit the growth of more than 23 microorganisms and no resistance has been found ${ }^{11}$. Microorganisms are growing resistant to most antibiotics due to noncompliance and abuse by it users, hence, it is recommended that pharmaceutical companies formulate garlic extract into drugs (including ophthalmic) to help combat microbial infections. 
TABLE 1: GARLIC AND GENTAMICIN SENSITIVITY WITH STAPHYLOCOCCUS AUREUS

\begin{tabular}{|l|l|l|l|}
\hline & Zones of Inhibition & Average $(\mathrm{mm})$ \\
\hline Treatment & $\begin{array}{l}\text { Vertical diameter } \\
(\mathrm{mm})\end{array}$ & $\begin{array}{l}\text { Horizontal diameter } \\
(\mathrm{mm})\end{array}$ & 25 \\
\hline Garlic extract & 25 & 33 & 25 \\
\hline Gentamycin & 32 & 32.5 \\
\hline
\end{tabular}

TABLE 2: TEST OF THE MINIMUM INHIBITORY CONCENTRATION (MIC) OF GARLIC ON STAPHYLOCOCCUS AUREUS

\section{Zones of Inhibition}

\begin{tabular}{|l|l|l|l|}
\hline $\begin{array}{l}\text { Garlic concentration } \\
(\mathrm{mg} / \mathrm{ml})\end{array}$ & $\begin{array}{l}\text { Vertical diameter } \\
(\mathrm{mm})\end{array}$ & $\begin{array}{l}\text { Horizontal diameter } \\
(\mathrm{mm})\end{array}$ & Average $(\mathrm{mm})$ \\
\hline 250 & 25 & 25 & 25 \\
\hline 125 & 18 & 19 & 18.5 \\
\hline 62.5 & 12 & 12 & 12 \\
\hline 31.25 & 9 & 9 & 9 \\
\hline
\end{tabular}

TABLE 3: $\quad$ BIOLOAD OF DIFFERENT GROUPS OF RABBITS AT DIFFERENT DAYS AS TREATMENT PROGRESSED

\begin{tabular}{|l|l}
\hline Group & Bacterial load in Colony forming unit (CFU) \\
\hline
\end{tabular}

\begin{tabular}{|l|l|l|l|l|l|l|l|l|}
\hline & $0 \mathrm{hr}$ & $48 \mathrm{hrs}$ & $95 \mathrm{hrs}$ & $144 \mathrm{hrs}$ & $192 \mathrm{hrs}$ & $240 \mathrm{HRS}$ & $288 \mathrm{hrs}$ & $336 \mathrm{hrs}$ \\
\hline $\mathrm{A}$ & - & $1.6 \times 10^{5}$ & $2.1 \times 10^{3}$ & $2.0 \times 10^{2}$ & $2.75 \times 10^{0}$ & - & - & - \\
\hline $\mathrm{B}$ & - & $1.55 \times 10^{5}$ & $3.91 \times 10^{2}$ & $8.6 \times 10^{0}$ & - & - & - & - \\
\hline $\mathrm{C}$ & - & $1.54 \times 10^{5}$ & $1.63 \times 10^{5}$ & $9.0 \times 10^{4}$ & $1.77 \times 10^{3}$ & $1.8 \times 10^{2}$ & $7.4 \times 10^{0}$ & $5.75 \times 10^{0}$ \\
\hline
\end{tabular}

\section{R E F E R E N C E S}

1. Gilbert, C. and Senaratne, T. T. (2005): Conjunctivitis. J. Com. Hlth. 18(53): 73-5.

2. Baba, I. (2005): The Red Eye First aid at the Primary level. J. Com. Hlth., 18(53): 70-2.

3. Koch, H. P. and Lawson, L. D. (1996): Garlic, the science and therapeutic application of allium sativum and related species. Willams and Wilkins, Baltimore, pp. 1-233.

4. Nkwocha, L. (2004): Effect of Garlic on some Visual function. Clin. Infect. Dis. 19:1123-8.

5. Berwal, J. S. and Kumar, M. (1998): Sensitivity of food pathogens to garlic. J. Appl. Microbiol, 84:213-5.

2. Kanski, J. J. (1998): Clinical Ophthalmology. $3^{\text {rd }}$ Edn. Butterworth-Heinemann, 514pp.

7. Sasaki, J. (1999): Practical use of Garlic powder. J. Nutr. Sci. Vitaminol, 45 (6): 785-90.

8. Gonzalez, F. F., Garcia, L. M., Sierra, M. and Otero, A. (1994): Staphylococal growth and enterotoxins (A-D) and thermonuclease synthesis in the presence of dehydrated garlic. J.Appl. Bact. 77: 549-52.

9. Uchida, Y., Takahashi, T. and Sata, N. (1975): The Characteristic of antibacterial; l activity of Garlic. Jap. J. Antibiotic. 28: 638-42.

10. Limson, J. (2001): The Science behind the Legendary Healing Prosperities of Garlic. Sci. Afri, 17:10. 